\title{
THE TIMING OF INITIAL PUBLIC OFFERINGS - NON-NUMERICAL MODEL BASED ON QUALITATIVE TRENDS
}

\author{
Tomáš MELUZÍN ${ }^{1}{ }^{(\mathbb{D})}$ Marek ZINECKER $^{2}{ }^{(\mathbb{D})}$; Adam P. BALCERZAK $^{3^{*} \text { (D) }}$; \\ Karel DOUBRAVSKÝ ${ }^{4}$; Michał B. PIETRZAK ${ }^{(\mathbb{D})}$; Mirko DOHNAL ${ }^{6}$ \\ 1, 2, 4, ${ }^{B}$ Brno University of Technology, Faculty of Business and Management, \\ Kolejní 2906/4, 61200 Brno, Czech Republic \\ ${ }^{3,5}$ Nicolaus Copernicus University in Torun, Faculty of Economic Sciences and Management, \\ ul. Gagarina 13a, 87-100 Toruń, Poland
}

Received 26 September 2017; accepted 14 March 2018

\begin{abstract}
The objective of this study is to develop a qualitative model supporting chief financial officers (CFOs) while considering the timing of initial public offerings (IPOs) under conditions of underdeveloped capital markets, where decision making is often made under information shortage. A lack of adequate statistical data in connection with turbulently changing environment suggests that additional research is needed to develop new IPO timing models based not only on statistical analyses. We used a qualitative research approach based on trends, which are increasing, constant or decreasing. Firstly, we identified key variables influencing IPO timing, which have sufficient support in the relevant IPO academic literature, e.g. GDP growth rates, level of compliance, stock market returns, etc. Next, a qualitative model working with 9 variables was developed. The result is represented by 19 scenarios and their qualitative solutions. The transitional graph represents all possible transitions among the 19 scenarios. The main message of the findings presented is what scenarios can occur and what actions might be implemented by CFOs in order to increase the chances of IPO success. We believe that our findings provide valuable implications for local issuers, investment bankers, stock exchanges and macroeconomic policy makers.
\end{abstract}

Keywords: initial public offering, IPO, timing, determinants, macroeconomics, microeconomics, heuristics, qualitative, scenario, transition.

JEL Classification: E44, G23, G32.

\section{Introduction}

Recent academic theories and empirical research identified many endogenous and exogenous determinants that may have significant effects on the timing of initial public offerings (IPOs). There are many empirical studies that have surveyed this issue in well-developed capital markets of the USA and Western Europe (e.g. Ibbotson, \& Jaffe, 1975; Ritter, 1984, 2011; Brau, \&

*Corresponding author. E-mail: adam.balcerzak@umk.pl

This is an Open Access article distributed under the terms of the Creative Commons Attribution License (http://creativecommons. org/licenses/by/4.0/), which permits unrestricted use, distribution, and reproduction in any medium, provided the original author and source are credited. 
Fawcett, 2006; Bancel, \& Mittoo, 2009; Ritter, \& Welch, 2002; Chemmanur, \& Fulghieri, 1999; Pagano, Panetta, \& Zingales, 1998; Black, \& Gilson, 1998). However, to our knowledge this phenomenon has been investigated very poorly in the Central and Eastern European (CEE)

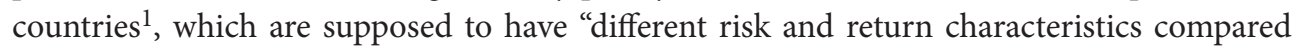
with developed EU's markets". The Warsaw Stock Exchange (WSE) is considered to be the only capital market in the CEE region playing an essential role in capital raising and belongs to those capital markets in Europe recording high IPO numbers and volumes (IPO Watch Europe 2004-2015). The remaining capital markets have never started to provide a real channel for acquiring sources of financing for enterprises to a significantly greater extent. Both IPO volumes and numbers remain substantially lower in most CEE markets (for details about IPO volumes and values see Figure 1). The interrelationships among selected Central and Eastern European capital markets have been documented by e.g. Fałdziński, Balcerzak, Meluzín, Pietrzak, and Zinecker (2016) and Pietrzak, Fałdziński, Balcerzak, Meluzín, and Zinecker (2017).

Therefore, the majority of the CEE countries do not provide sufficient historical data and we suggest that in connection with turbulently changing environment the established IPO timing models have obvious limitations. Conventional statistical analyses, which are directly or indirectly based on the law of large numbers and using macro- and micro-data, are not applicable (Loeve, 1977; Haefke, \& Helmenstein, 1996; Theodoridis, \& Koutroumbas, 2008; Myskova, 2009; Hajek, Olej, \& Myskova, 2014). An alternative, how to capture fundamental features of a system while eliminating quantitative details, represent qualitative models. Qualitative models are defined as uncertainty calculi. Fuzzy sets, rough sets and order of magnitude reasoning are examples of them.

In this study, we intend to fill a gap in the academic literature on going public by developing a qualitative model supporting chief financial officers (CFOs) on IPO timing. The novelty of this study consists in the research approach based on non-numerical modelling. To our knowledge, the previous academic literature has not applied qualitative on trends based models supporting decision making of CFOs on IPO timing in any of the emerging capital markets where the corporate practice grapples with insufficient statistical data records.

This paper contributes to a better understanding of decision-making on public issues in the sector of private enterprises. Modelling determinants on IPO timing is a starting point while formulating new financial strategies of e.g. banking or venture capital backed companies. We also expect that our findings will be beneficial for investment bankers, stock exchanges and macroeconomic policy makers while discussing and designing incentives how to attract more enterprises onto the primary capital markets under the specific conditions of CEE countries.

The methods employed in this article include systematic and logical literature analysis, collecting of original data (structured interviews with experts in the IPO industry), qualitative modelling, comparison and expert interpretations.

This paper is structured as follows. Section 1 reviews IPO literature on IPO timing. Section 2 describes the research design. Section 3 presents the model proposal supporting and the last section summarizes and provides concluding remarks.

\footnotetext{
${ }^{1}$ We define CEE capital markets as former Eastern Bloc countries (until 1989) which recorded a significant IPO activity in recent two decades. Therefore, we list the countries as follows: Czech Republic, Poland, Hungary, Slovenia, Romania, Bulgaria and Croatia.
} 

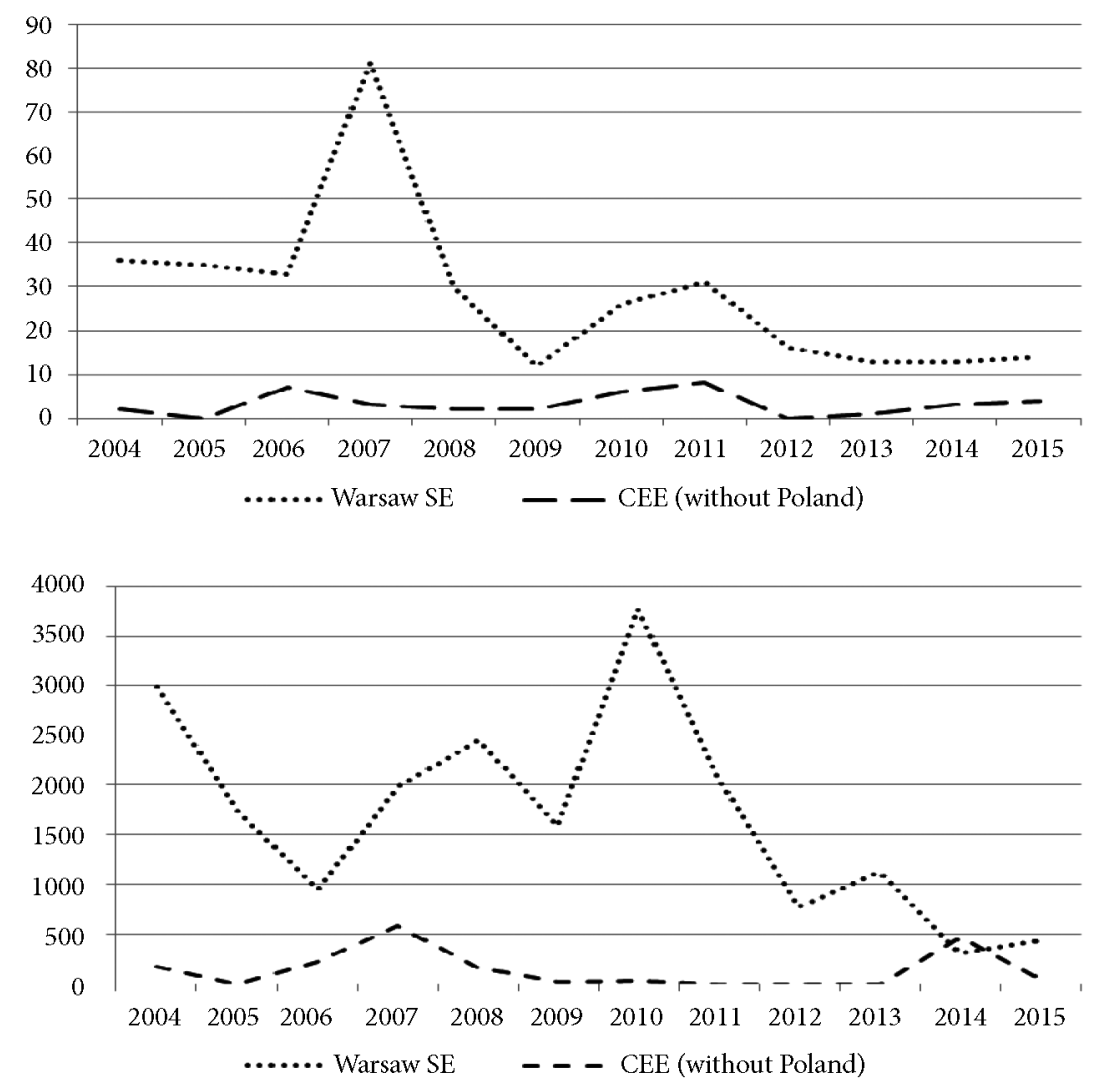

Figure 1. Number of IPOs (above) and IPO values (in EUR m) in the period between 2004 and 2015 (below). Source: authors' calculations based on FESE (2015); PwC IPO Watch Europe (2017).

\section{Theoretical framework}

Companies going public consider a broad range of exogenous and endogenous determinants affecting the decision related to the timing of initial public offerings (IPOs). The current academic studies highlight the underlying economic conditions as well as firm specific characteristics.

Ibbotson and Jaffe (1975), Ritter (1984) and Loughran, Ritter, and Rydqvist (1994) argue that IPOs have a cyclical character, because managers tend to take advantage of temporarily attractive market conditions and stock prices (the windows-of-opportunity hypothesis). The authors focused on the prediction of "hot" issue markets which are defined as periods in which the first-month stock performance or aftermarket performance of firms going public is abnormally high. Based on the results of statistical tests the authors postulate that companies go public under favourable economic conditions that support their growth and development. In a growing stage of the business cycle companies going public experience a "hot" market characterized by an increase in number of enterprises going public as well as proceeds, 
during a recession the number of companies going public slows down. On the other hand, the studies conducted by Rydqvist and Högholm (1995) and Loughran et al. (1994) show that the GDP short-term growth rates are no significant explanatory power for IPO activity across the sample of European countries. In a similar way, Breinlinger and Glogova's analysis (2002) of annual IPO volumes for six continental European countries could not support the hypothesis that GDP growth rates have explanatory power for IPO volumes. Contrariwise, La Porta et al. (1997) detected the influence of the legal system on the number of IPOs using a sample of 49 countries. The results show that "the quality of law enforcement, which is highly correlated with the level of GDP per capita, has a strong positive effect on the number of IPOs". Moreover, the authors identified a statistically significant influence of long-term GDP growth rates on going public activity in investigated countries.

Jovanovic and Rousseau (2004) model the IPO timing decision and suggest that a non-monotonic relation exists between interest rate and the number of IPOs. At low interest rates companies tend to delay going public while very high rates of interest also discourage the IPO activity. Rees (1997) based on analysis of UK data states that there is no significant link between the number of IPOs and interest rates. Similarly Breininger and Glogova (2002) also indicate that there is no perceivably influence of interest rates (ten-year government bond yields) on demand for capital raising through IPOs.

Loughran et al. (1994), Ljungqvist (1995), Rees (1997) and Rydqvist and Högholm (1995) identified a significantly positive influence of stock index levels and stock index returns on the number of IPOs. Loughran et al. (1994) investigate the timing of IPOs in fifteen countries in relation to inflation-adjusted stock price indexes and GDP growth rates. The results suggest a positive relationship between the number of IPOs and stock price levels, however no positive correlation with the cycle movements. Rydqvist and Högholm (1995) compare the data for a sample of family-owned enterprises in Sweden (1970-1991) and eleven European countries (1980-1989). They find that "most going public activity took place after an exceptionally sharp stock price increase, and that going public activity is not related to the business cycle". Ljungqvist (1995) suggests that high number of IPOs is positively correlated with both high stock index levels and good business conditions and tends to follow phases of extensive IPO underpricing. Brzeszczynski (2014) studied the volumes of new IPOs and the main stock market index (WIG) returns for the Polish stock market over a period from 1997 to 2008. The author concludes that the IPO activity is linked to macroeconomic conditions, business cycles and stock market activity while a time lag between movements of the stock market index and decisions to conduct new IPOs exists.

The quality and adequacy of the institutional framework in regard to the capital market development is highlighted in many other studies (e.g. Balcerzak, \& Pietrzak, 2016; Pohulak-Żołędowska, 2016; Meluzín, \& Zinecker, 2016; Pietrzak et al. 2017; Kubiszewska, 2017; Żelazny \& Pietrucha, 2017). In this context the differences in the development of the institutional framework in the Czech and Polish capital market have been investigated since the 1990s. The development of these markets and their importance to the economy differ fundamentally. There is a consensus in the literature that the relative success of the Polish compared to the relative failure of the Czech capital market is due to much stronger regulatory environment and law enforcement in Poland at the beginning of the establishing of security markets (e.g. Aussenegg, 1999; Aussenegg, \& Jelic, 2007). 
Choe, Masulis, and Nanda (1993) report that companies prefer to go public when other good firms are currently conducting an IPO. Pagano et al. (1998) and Loughran et al. (1994) find that "hot" issue markets do not coincide with urgent funding needs and subsequent investments. Firms' going public decision seem to be driven mainly by market timing attempts (Baker, \& Wurgler, 2000). Peterle and Berk (2016) report on the incentives for IPOs in the CEE in the 2000s and proved that IPO cycles in the region exist. The authors suggest that IPO activity is driven by macroeconomic conditions and the investors' sentiment.

Lowry (2003) explored extreme fluctuations in IPO volume over 37 years. He compares "the extent to which the aggregate capital demands of private firms, the adverse-selection costs of issuing equity, and the level of investor optimism can explain these fluctuations. Results indicate that firms' demands for capital and investors' sentiment determine IPO volume, in both statistical and economic terms."

Consistent with these results are findings of a survey conducted by Burgstaller (2005). He examined public issues on the Vienna Stock Exchange between 1985 and 2004. The author delivers evidence concerning the aggregate factors that explain the time-series variation in both the numbers of and proceeds from initial public offerings and seasoned equity offerings (SEOs). Results indicate that firms successfully time their offerings to take advantage of high stock market valuations and the associated low cost of equity capital. The proceeds from IPOs, rather than funds raised by firms that are already listed, are used to finance subsequent investment.

Brau and Fawcett (2006) asked 336 US chief financial officers (CFOs) to compare practice to theory inter alia in the area if IPO timing. Overall stock market conditions were identified as the single most important determinant of IPO timing. Two other factors were also perceived as strongly influencing the timing of an IPO: industry conditions and the need for capital to support growth. On the contrary, two other explanations - other good firms are currently going public and first day stock performance of recent IPOs - were viewed as relatively unimportant. The data suggest that CFOs do pursue windows of opportunity, but they define these windows in terms of overall stock market and industry conditions and not by the IPO market. Bancel and Mittoo (2009) surveyed survey CFOs from 12 European countries regarding the IPO determinants and exchange listing decisions. The authors report a rather low support for the windows-of-opportunity hypothesis. Only $40 \%$ of respondents agree that the IPO has allowed the issuing companies "to benefit from favourable market conditions (such as, bullish stock exchange/industry valuation)." The authors find strong support for the IPO theories (Maksimovic, \& Pichler, 2001) emphasizing "financial and strategic considerations, such as enhanced reputation and credibility, and financial flexibility as a major advantage of an IPO”.

The trade-off theory represents another theory explaining the IPO timing. Pagano et al. (1998) suggest that companies that face higher interest rates and have more concentrated credit sources are more likely to go public. The going public strategy is viewed as a tool how to achieve an optimal capital structure and to lower the cost of capital (Scott, 1976; Modigliani, \& Miller, 1958, 1963). Thus, there is a general believe that firms conduct IPOs when other financial sources are not available because of a high leverage.

The relationship between profitability and going public probability is unambiguous. Pagano et al. (1998) suggest a negative relation because only such companies prefer external 
sources which are not able to generate sufficient internal cash flow. On the other hand, Ritter (1984) argues that a temporary increase in profitability may encourage companies to go public to capture the "window of opportunity".

\section{Qualitative knowledge: the conceptual framework}

It follows from the theoretical framework that much shallow knowledge on IPO timing is available. CFOs in the most CEE countries, however, cannot use statistical tests requiring a minimum number of data that correspond to the required accuracy; (e.g. multiple regression analysis, factor analysis, main component analysis, etc.). For details see e.g. Gujarati and Porter (2009) and Ross (2017). Any elimination of information shortages is inevitably based on incorporations of non-numerical information items, for example fuzzy/rough models (Chen, \& Cheng, 2012). Therefore, CFOs as experts have to rely on knowledge represented by common-sense logic/reasoning. In this paper, qualitative modelling is applied as an alternative approach to analyses based strictly on statistical data.

Pair wise relations are a typical example of qualitative modelling. All pair wise relations $X, Y$ in Figure 1 are trend relations. For example the relation 24 indicates that:

1) The relation $Y=f(X)$ is decreasing, i.e. the first derivative is negative; $d Y / d X=-$.

2) The decrease slows down, i.e. the second derivative is therefore negative, $d Y^{2} / d X^{2}=+$.

3) If $X=0$ then $Y>0$.

The points 1, 2 and 3 demonstrate that no quantitative values are required to formalise the shapes given in Figure 2.
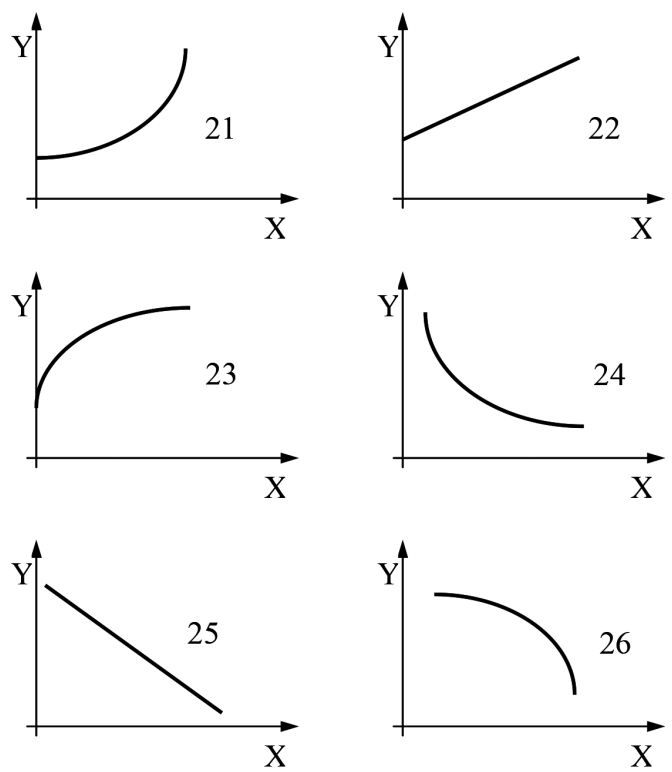

Figure 2. Examples of qualitative pair wise relations Source: authors' work. 
The principal of qualitative modelling consists in the quantifiers as follows:

$\begin{array}{lllll}\text { Values: } & \text { Positive } & \text { Zero } & \text { Negative } & \text { Anything } \\ \text { Derivatives: } & \text { Increasing } & \text { Constant } & \text { Decreasing } & \text { Any direction } \\ \text { Symbol: } & + & 0 & - & *\end{array}$

where $X_{i}$ is the $i$-th variable and $D X_{i}$ and $D D X_{i}$ are the first qualitative and second qualitative derivations with respect to time $t$. A set $S$ of $m$-qualitative $n$-dimensional scenarios is described by the following set of triplets:

$$
S=\left[\left(X_{1}, D X_{1}, D D X_{1}\right),\left(X_{2}, D X_{2}, D D X_{2}\right), \ldots,(X n, D X n, D D X n)\right] j,
$$

where $j=1,2, \ldots, m$.

The triplet $\left(X_{i}, D X_{i}, D D X_{i}\right)$ is based on the first and second derivative. IPO knowledge is relatively poor and therefore the third derivatives are unknown.

A simple transfer of quantitative derivative $d x_{i} / d t$ to the qualitative derivatives is:

$$
\begin{aligned}
& \text { if } d x i / d t>0 \text { then } D X i=+ \\
& \text { if } d x i / d t=0 \text { then } D X i=0, \\
& \text { if } d x i / d t<0 \text { then } D X i=- \text {. }
\end{aligned}
$$

There are only three qualitative values (1) if the value anything * is ignored. Let us suppose that that all IPO variables are positive.

$$
X_{i}=+; i=1,2, \ldots, n \text {. }
$$

For example the share price is always positive. The maximum possible number of qualitatively distinguishable scenarios (2) can be evaluated by the following formula:

$$
(3 d)^{n} \text {. }
$$

The order of derivation used in this paper is two, $d=2$. Therefore just the first and second derivatives $D, D D(2)$ are used.

Shallow heuristics are formalised by pairwise relations, see Figure 1. A qualitative model is a set of $w$ pair wise relations:

$$
\operatorname{Ps}\left(X_{i}, X_{j}\right)
$$

where $s=1,2, \ldots, w$.

This set of $w$ relations can be solved to asses all such scenarios which are in accordance with the model (6). An example represents the set of two relations as follows:

$\begin{array}{lll}\text { Shape } & X & Y \text {, see Figure 1 } \\ \text { 1 (no. 22, see Figure 1) } & X_{1} & X_{2}, \\ 2 \text { (no. 26, see Figure 1) } & X_{3} & X_{2} .\end{array}$

An algorithm which can be used to solve the model (7) can be based on methods used in artificial intelligence - pruning/simplifying of a one-root tree. It is a purely combinatorial/ formal mathematical task and is not studied in this paper.

Each scenario must be either accepted as a solution of the model (6), see e.g. (7), or rejected. To simplify the problem let us suppose that all three variables $X_{1}, X_{2}$ and $X_{3}$ are 
positive as it requires the very nature of IPO. For example, $X_{1}$ is an interest rate and this is always positive. Therefore the following triple is used: (+, DX1, DDX1).

Another simplification is that the second derivatives are ignored or not known. It means that just the following triplet is used $\left(+, D X 1,{ }^{*}\right)$, see $(1)$.

If the second derivatives are not known then the model (7) is simplified as follows:

1 If $X_{1}$ is increasing then $X_{2}$ is increasing. If $X_{1}$ is decreasing then $X_{2}$ is decreasing.

2 If $X_{3}$ is increasing then $X_{2}$ is decreasing. If $X_{3}$ is decreasing then $X_{2}$ is increasing.

The model (6) is therefore simplified into the following set of two relations:

where:

$$
\begin{aligned}
& Q P+X_{1} X_{2}, \\
& Q P-X_{3} X_{2},
\end{aligned}
$$

$Q P+$ qualitative direct proportionality,

$Q P-$ qualitative indirect proportionality,

$Q P+$ covers all three increasing shapes; see no. 21, 22 and 23, Figure 1,

$Q P$ - covers all three decreasing shapes; see no. 24, 25 and 26, Figure 1.

Qualitative proportionalities $Q P(9)$ are knowledge items requiring the lowest level of information. Two variables cannot be related by a qualitative proportionality only in the case when nothing is known about their relationship.

\section{IPO timing: the model}

Our model describes decision making on IPO timing in capital markets with insufficient historical records. Most CEE capital markets are an example. CFOs, especially at the very beginning of a complex analysis, cannot use mathematical models as the basic background for their reasoning. Experts are forced to draw heavily on knowledge represented by commonsense. The central question to be addressed here is: "How can we assess whether a scenario is possible?" This can be identified based on the shallow knowledge about trends of key variables described in section 1 .

At the beginning a set of twelve variables was identified (see Table 1). All listed variables have sufficient support in substantial academic literature and were discussed with experts in the area of IPOs. The desired values of the first derivatives of all explanatory variables are given in the third column. A positive derivative of e.g. GDP means that GDP is increasing. If the second derivative of $G D G$ is positive as well then the increase is more and more rapid. This is the reason why the best qualitative behavior of an objective function $Q$ is the triplet $(+++)$ for the maximization and $(+--)$ for the minimization.

We have to keep in mind that in a scenario each variable is represented by a qualitative triplet (X, DX, DDX), for details see section 2. There are 9 variables in our model, hence 9 triplets in each scenario. Each value in the triplet can be either,+- or 0 . Thus, there are $3^{3}=27$ possible combinations for each triplet. Since we have 9 of such triplets (one for each variable) in each scenario, there are $27^{9}$ possible combinations of,+- and 0 , where each combination represents a possible scenario. This vast number of $27^{9}$ scenarios has to be reduced to receive an applicable solution. 
Table 1. Set of variables influencing IPO timing

\begin{tabular}{|l|l|l|l|}
\hline \multicolumn{1}{|c|}{ Explanatory Variables } & $\begin{array}{l}\text { Abbre- } \\
\text { viation }\end{array}$ & \multicolumn{1}{|c|}{ Substantial Theory } & $\begin{array}{l}\text { Desired } \\
\text { Trend }\end{array}$ \\
\hline \% Real GDP Growth Rates & GDP & La Porta et al. (1997) & increase \\
\hline $\begin{array}{l}\text { \% Ten-Year Government } \\
\text { Bond Yields }\end{array}$ & GBY & Jovanovic and Rousseau (2004) & decrease \\
\hline $\begin{array}{l}\text { \% Change in Stock Market } \\
\text { Index Returns }\end{array}$ & SIR & $\begin{array}{l}\text { Loughran } \text { et al. (1994); Ljungqvist (1995); Rees } \\
\text { (1997); Rydqvist and Högholm (1995) }\end{array}$ & increase \\
\hline $\begin{array}{l}\text { Growing Number of } \\
\text { Domestic Listed Companies }\end{array}$ & DLC & Choe et al. (1993) & increase \\
\hline $\begin{array}{l}\text { Law in the Area of the } \\
\text { Capital Market Regulation }\end{array}$ & CMR & $\begin{array}{l}\text { La Porta } \text { et al. (1997); Aussenegg (1999); Aus- } \\
\text { senegg and Jelic (2007) }\end{array}$ & increase \\
\hline $\begin{array}{l}\text { Company Growth } \\
\text { Publicity, Image Enhancement }\end{array}$ & CIM & $\begin{array}{l}\text { Brau and Fawcett (2006); Bancel and Mittoo } \\
\text { (2009) }\end{array}$ & increase \\
\hline Leverage & LEV & Scott (1976); Modigliani and Miller (1958, 1963) & increase \\
\hline ROA & ROA & Ritter (1984) & increase \\
\hline
\end{tabular}

Source: authors' calculations.

As a next step of our model development, we defined that all variables have only positive values. It means that $3^{2}=9$ combinations for each triplet exist. Since there are 9 of such triplets, we obtain $9^{12}$ possible combinations.

Subsequently, we defined individual interrelations within the model. In Table 2 pairwise relations are displayed. The second column indicates the number of the corresponding qualitative shapes, see Figure 2 or $\mathrm{QP}+$, and see (9). There is a set of 25 pairwise relations (Table 2). The relations are formalised by the shapes given in Figure 2.

Table 2. Qualitative IPO timing model represented by a set of pair-wise relations

\begin{tabular}{|c|c|c|c|c|c|c|c|}
\hline $\begin{array}{c}\text { Statement } \\
\text { No. }\end{array}$ & Shape & $X$ & $Y$ & $\begin{array}{c}\text { Statement } \\
\text { No. }\end{array}$ & Shape & $X$ & $Y$ \\
\hline 1 & 23 & GDP & IPO & 14 & QP+ & SIR & CIM \\
\hline 2 & 24 & GDP & GBY & 15 & QP+ & SIR & CGR \\
\hline 3 & 23 & GDP & SIR & 16 & QP- & SIR & LEV \\
\hline 4 & 23 & GDP & DLC & 17 & QP+ & SIR & ROA \\
\hline 5 & 23 & GDP & CGR & 18 & QP+ & CMR & IPO \\
\hline 6 & 23 & GDP & ROA & 19 & QP+ & CMR & DLC \\
\hline 7 & 24 & GBY & IPO & 20 & QP- & CMR & LEV \\
\hline 8 & 24 & GBY & SIR & 21 & QP+ & CIM & IPO \\
\hline 9 & 24 & GBY & CGR & 22 & QP+ & CIM & CGR \\
\hline 10 & 24 & GBY & LEV & 23 & QP+ & CIM & ROA \\
\hline 11 & 24 & GBY & ROA & 24 & 23 & CGR & LEV \\
\hline 12 & 23 & SIR & IPO & 25 & 23 & CGR & ROA \\
\hline 13 & 23 & SIR & DLC & & & & \\
\hline
\end{tabular}

Note: See Figure 2 for the respective shapes, such as "23", "24", etc.

Source: authors' calculations. 
Using the principle of consistency, a set of 19 scenarios, $m=19$ (2) is the solution of the model, see Table 3. The set of scenarios (2) is not the only useful result of the qualitative model given in Table 2. Time transitions among the scenarios can be generated to get a transitional graph, see Figure 3. For example it is obvious that the scenario No. 1 can be transferred into the scenario No. 2 or 4 (see Table 3). There is no transition from the scenario No. 1 to the scenario No. 5 .

All variables are either exogenous, i.e. decision makers have them not under control (i.e. lotteries), or endogenous, i.e. decision makers have them under control (i.e. controlled variables). The decision maker can therefore just passively observe changes of exogenous variables or act when influencing endogenous variables. The transitional graph makes sure that no variant is overlooked, i.e. covers all possible time changes.

Let us suppose that all variables are lotteries. Thus, any unsteady macroeconomic and capital market conditions can be described by a time sequence of scenarios $S$ (2). If each scenario is represented by a node and all transitions are graphically represented by oriented arks between corresponding pairs of scenarios, the result is an oriented graph of all possible transitions. Any time behaviour of the macroeconomic and capital market environment can be characterised as a path(s) in the transition graph. The transition graph is thus a condensed description of all possible unsteady state behaviors.

Table 3. Scenarios

\begin{tabular}{|c|c|c|c|c|c|c|c|c|c|c|c|}
\hline $\begin{array}{l}\text { Sce- } \\
\text { nario }\end{array}$ & GDP & IPO & GBY & SIR & DLC & CGR & ROA & LEV & CMR & CIM & CGR \\
\hline 1 & +++ & +++ & +-+ & +++ & +++ & +++ & +++ & +++ & +++ & +++ & +++ \\
\hline 2 & +++ & +++ & +-+ & +++ & +++ & +++ & +++ & ++0 & +++ & +++ & +++ \\
\hline 3 & +++ & +++ & +-+ & +++ & +++ & +++ & +++ & ++- & +++ & +++ & +++ \\
\hline 4 & +++ & +++ & +-0 & +++ & +++ & +++ & +++ & +++ & +++ & +++ & +++ \\
\hline 5 & +++ & +++ & +-- & +++ & +++ & +++ & +++ & +++ & +++ & +++ & +++ \\
\hline 6 & +++ & ++- & +-+ & ++- & ++- & ++- & ++- & ++- & ++- & ++- & ++- \\
\hline 7 & ++0 & ++- & +-+ & ++- & ++- & ++- & ++- & ++- & ++- & ++- & ++- \\
\hline 8 & ++- & ++- & +-+ & ++- & ++- & ++- & ++- & ++- & ++- & ++- & ++- \\
\hline 9 & $+0+$ & $+0+$ & $+0-$ & $+0+$ & $+0+$ & $+0+$ & $+0+$ & $+0+$ & $+0+$ & $+0+$ & $+0+$ \\
\hline 10 & +00 & +00 & +00 & +00 & +00 & +00 & +00 & +00 & +00 & +00 & +00 \\
\hline 11 & $+0-$ & $+0-$ & $+0+$ & $+0-$ & $+0-$ & $+0-$ & $+0-$ & $+0-$ & $+0-$ & $+0-$ & $+0-$ \\
\hline 12 & +-+ & +-+ & +++ & +-+ & +-+ & +-+ & +-+ & +-+ & +-+ & +-+ & +-+ \\
\hline 13 & +-+ & +-+ & +++ & +-+ & +-+ & +-+ & +-+ & +-0 & +-+ & +-+ & +-+ \\
\hline 14 & +-+ & +-+ & +++ & +-+ & +-+ & +-+ & +-+ & +-- & +-+ & +-+ & +-+ \\
\hline 15 & +-+ & +-+ & ++0 & +-+ & +-+ & +-+ & +-+ & +-+ & +-+ & +-+ & +-+ \\
\hline 16 & +-+ & +-+ & ++- & +-+ & +-+ & +-+ & +-+ & +-+ & +-+ & +-+ & +-+ \\
\hline 17 & +-+ & +-- & +++ & +-- & +-- & +-- & +-- & +-- & +-- & +-- & +-- \\
\hline 18 & +-0 & +-- & +++ & +-- & +-- & +-- & +-- & +-- & +-- & +-- & +-- \\
\hline 19 & +-- & +-- & +++ & +-- & +-- & +-- & +-- & +-- & +-- & +-- & +-- \\
\hline
\end{tabular}

Source: authors' calculations. 
Let us suppose that the market situation under study corresponds to the scenario No. 16, see Figure 3. Our intention is to describe a realistic time sequence of scenarios reflecting changes of independent variables which affect the prospective IPO failure or success and thus IPO timing. The qualitative tree indicating how to reach a more or less favourable environment is relevant to the decision maker. In our case study, the scenarios No. 10, 1 and 3 are terminals of the qualitative tree. Each terminal scenario has its hypothetical value of capital raised by IPO.

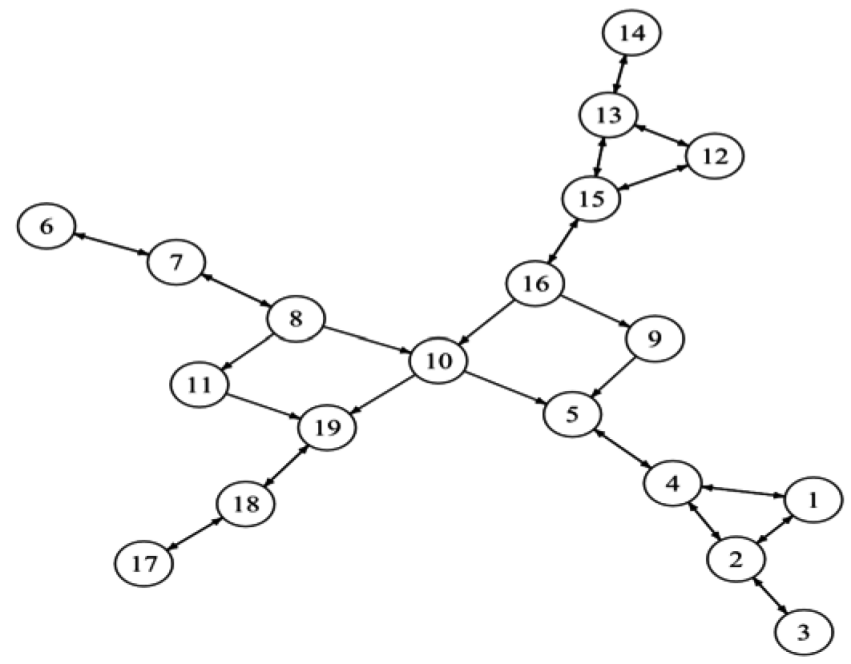

Figure 3. Transition graph

Source: authors' calculations.

The scenario no. 10 indicates rather unfavourable macroeconomic conditions, i.e. poor growth rates of GDP, low stock index returns, and increase of the cost of external capital. The quantitative and qualitative indicators of the particular capital market, i.e. its size, liquidity and institutions, affect the likelihood of going public. The scenario no. 3 indicates a projection of such a state of external environment, i.e. national and global economy, which obviously supports positive going public decisions. Favourable development of exogenous and endogenous variables suggests a window of opportunity while attracting investors to new issues.

Scenario Value of capital raised through IPO (mil. EUR), (see Figure 3):

No. $10 \quad 100$,

No. 1 150,

No. 3200 .

The heuristic (11) is used to evaluate the qualitative tree, see Figure 6. The total ignorance case has the solution given in Table 4.

A common sense interpretation of the heuristic (11) indicates that the shortest branch, i.e. the transfer scenario $16 \rightarrow 10$ of the qualitative tree (see Figure 6), has the dominant probability. It is easy to evaluate the capital raised by IPO using the results given in Table 5 . 
Table 4. Probabilities of transitions evaluated by the heuristic (11) - total ignorance case

\begin{tabular}{|c|c|c|}
\hline \multicolumn{2}{|c|}{ Transition from scenario $i$ to scenario $j$, see Figure 6} & \multirow{2}{*}{ Probability of transition } \\
\hline$i$ & $j$ & 0.857 \\
\hline 16 & 10 & 0.143 \\
\hline 16 & 9 & 1 \\
\hline 9 & 5 & 1 \\
\hline 5 & 4 & 0.667 \\
\hline 4 & 1 & 0.333 \\
\hline 4 & 2 & 1 \\
\hline 2 & 3 & \\
\hline
\end{tabular}

Source: authors' calculations.

Table 5. Probabilities of the IPO success and the mean value

\begin{tabular}{|c|c|c|}
\hline Terminal & Capital Raised by IPO & Probability \\
\hline $\mathrm{i}$ & {$[\mathrm{mil} \in]$} & $\mathrm{p}$ \\
\hline 10 & 100 & 0.857 \\
\hline 1 & 150 & 0.095 \\
\hline $3 \quad 200$ & 0.048 \\
\hline \multicolumn{2}{|c|}{$€$ Cash Flow (Mean Value) } & 109.55 \\
\hline
\end{tabular}

Source: authors' calculations.

A partial ignorance problem means that some probabilities are vaguely known and specified as fuzzy sets. Two fuzzy probabilities are given in Table 6.

Table 6. Fuzzy probabilities

\begin{tabular}{|c|c|c|c|c|}
\hline \multicolumn{2}{|c|}{ Transition from $i$ to $j$} & \multicolumn{3}{|c|}{ Fuzzy Probability } \\
\hline$i$ & $j$ & $a$ & $b=c$ & $d$ \\
\hline 16 & 10 & 0.65 & 0.7 & 0.95 \\
\hline 16 & 9 & 0.15 & 0.25 & 0.3 \\
\hline
\end{tabular}

Source: authors' calculations.

The probabilities of transfers $4 \rightarrow 1$ and $4 \rightarrow 2$ are not given. It means that the general heuristic (11) must be reconciled with the fuzzy sets given in Table 6. The reconciliation result is given in Table 7 .

Table 7. Probabilities of transitions - partial ignorance case

\begin{tabular}{|c|c|c|}
\hline \multicolumn{2}{|c|}{ Transition from $i$ to $j$} & \multirow{2}{*}{ Probability of Transition } \\
\hline 1 & $j$ & 0.75 \\
\hline 16 & 10 & 0.25 \\
\hline 9 & 9 & 1 \\
\hline 5 & 5 & 1 \\
\hline 4 & 4 & 0.667 \\
\hline 4 & 1 & 0.333 \\
\hline 2 & 2 & 1 \\
\hline
\end{tabular}

Source: authors' calculations. 
The corresponding mean value of the capital raised by IPO is given in Table 8 .

Table 8. Probabilities of the capital raised by IPO and the mean value

\begin{tabular}{|c|c|c|}
\hline Terminal No. & Capital raised by IPO & \multirow{2}{*}{ Probability } \\
\hline$i$ & {$[$ mil. $€]$} & 0.75 \\
\hline 10 & 100 & 0.167 \\
\hline 1 & 150 & 0.083 \\
\hline $3 \quad$ € Cash Flow (Mean Value) & 116.65 \\
\hline
\end{tabular}

Source: authors' calculations.

To demonstrate flexibility of the reconciliation algorithm the following sets of fuzzy probabilities are taken into reconciliation. The reconciliation results are given in Table 10 and Table 11.

Table 9. Fuzzy probabilities

\begin{tabular}{|c|c|c|c|c|}
\hline \multicolumn{2}{|c|}{ Transition from $i$ to $j$} & \multicolumn{3}{|c|}{ Fuzzy Probability } \\
\hline$i$ & $j$ & $a$ & $b$ & $c$ \\
\hline 16 & 10 & 0.65 & 0.7 & 0.95 \\
\hline 16 & 9 & 0.15 & 0.25 & 0.3 \\
\hline 4 & 1 & 0.8 & 0.85 & 0.9 \\
\hline 4 & 2 & 0.15 & 0.2 & 0.3 \\
\hline
\end{tabular}

Source: authors' calculations.

Table 10. Probabilities of transitions - partial ignorance case

\begin{tabular}{|c|c|c|}
\hline \multicolumn{2}{|c|}{ Transition from $i$ to $j$} & \multirow{2}{*}{ Probability of Transition } \\
\hline$i$ & $j$ & 0.75 \\
\hline 16 & 10 & 0.25 \\
\hline 9 & 9 & 1 \\
\hline 5 & 5 & 1 \\
\hline 4 & 4 & 0.85 \\
\hline 4 & 1 & 0.15 \\
\hline 2 & 2 & 1 \\
\hline
\end{tabular}

Source: authors' calculations.

Table 11. Probabilities of the capital raised by IPO and the mean value

\begin{tabular}{|c|c|c|}
\hline Terminal No. & Capital raised by IPO & Probability \\
\hline $\mathrm{i}$ & {$[$ mil. $€$ ] } & 0.75 \\
\hline 10 & 100 & 0.213 \\
\hline 1 & 150 & 0.037 \\
\hline
\end{tabular}

Source: authors' calculations. 


\section{Conclusions}

The statistical methods employed for the analysis of the IPO timing tasks require sufficient historical records. Unfortunately, a lack of adequate statistical data in connection with turbulently changing environment suggests that these precise statistical tools are not always suitable towards a full understanding of the task under study. We suggest that additional research is needed and we also believe that the principles and tools of qualitative modelling represent a suitable approach. Therefore, in this paper we intended to develop a qualitative IPO timing model supporting CFOs while considering going public under conditions of underdeveloped capital markets, where decision making is often made under information shortage.

Firstly, we identified key variables influencing IPO timing, which have sufficient support in the relevant IPO academic literature, e. g. GDP growth rates, level of compliance, stock market returns, etc. Next, we developed a qualitative IPO timing model represented by a set of pair-wise relations According to the principle of consistency, the initial set of all scenarios ( $27^{9}$ in our case study) was reduced to just 19 scenarios. Third, a transition graph was developed and a reconciliation algorithm was used to achieve better results based on qualitative heuristic and isolated quantitative information. The transition graph shows all transitions existing among 19 scenarios. Any path is a qualitative description of a forecast and the transitional graph $G$ represents all possible developments of external and internal environment. Fourth, heuristics were used to evaluate the qualitative tree.

The main scientific contribution of our research consists in enhancing of the qualitative model approach to forecast a complete set of scenarios while IPO timing. In our model no variant of future development can be overlooked, i.e. the model covers all possible changes of the external and internal environment. Moreover, it is possible to generate complicated unions and/or intersections of other IPO models developed by different experts. This aspect is important for development of classical quantitative models.

We believe that our findings provide valuable implications for corporate practice. CFOs considering going public have a tool how to predict future development. Scenarios for responding to possible changes of external and internal environment might be interconnected with additional resources of information to re-evaluate influence of key variables on IPO success or failure. The outcomes of this study are also valuable for issuers, investment bankers, stock exchanges and macroeconomic policy makers. The key question is what incentives should be implemented in order to increase the attractiveness of the local emerging capital markets for private companies and investors in the future? In order to encourage IPO emerging markets, policymakers, investment banks and stock exchanges should focus more on macroeconomic and institutional stability. The qualitative method forces the market participants to ask provocative questions and to re-evaluate their attitudes.

Qualitative models, however, require extensive expert knowledge and assistance to identify the broadest range of variants. Incorrect input quantities in combination with an erroneous estimate of trends are considered to be their major limitation. In this context, we aim to extend the data experiment in the follow-up research. In particular, we intend to enhance the existing list of IPO timing determinants by including variables related to internal ownership and governance factors and external factors such as governance at the country-level. 


\section{References}

Aussenegg, W. (1999). Going public in Poland: case-by-case privatizations, mass privatization and private sector initial public offerings. Michigan: William Davidson Institute at the University of Michigan, Stephen M. Ross Business School.

Aussenegg, W., \& Jelic, R. (2007). The operating performance of newly privatised firms in Central European transition cconomies. European Financial Management, 13(5), 853-879. https://doi.org/10.1111/j.1468-036X.2007.00400.x

Baker, M., \& Wurgler, J. (2000). The equity share in new issues and aggregate stock returns, Journal of Finance 55(5), 2219-2257. https://doi.org/10.1111/0022-1082.00285

Balcerzak, A. P., \& Pietrzak, M. B. (2016). Quality of institutions for knowledge-based economy within new institutional economics framework. Multiple criteria decision analysis for European countries in the years 2000-2013, Economics \& Sociology, 9(4), 66-81.

https://doi.org/10.14254/2071-789X.2016/9-4/4

Bancel, F., \& Mittoo, U. R. (2009). Why do European firms go public? European Financial Management, 15(4), 844-884. https://doi.org/10.1111/j.1468-036X.2009.00501.x

Black, B. S., \& Gilson, R. J. (1998). Venture capital and the structure of capital markets: banks versus stock markets, Journal of Financial Economics, 47(3), 243-277. https://doi.org/10.1016/S0304-405X(97)00045-7

Brau, J. C., \& Fawcett, S. E. (2006). Initial public offerings: an analysis of theory and practise. Journal of Finance 61(1), 399-436. https://doi.org/10.1111/j.1540-6261.2006.00840.x

Breinlinger, L., \& Glogova, E. (2002). Determinants of initial public offerings: a European time-series cross-section analysis. Working Paper. Financial Stability Report. Wien: Oesterreichische Nationalbank.

Brzeszczynski, J. (2014). IPOs in emerging markets. QFinance. Retrieved from http://www.qfinance. com/financing-best-practice/ipos-in-emerging-markets?full

Burgstaller, J. (2005). When and why do Austrian companies issue shares? Working Paper No. 0503. Linz: Johannes Kepler University.

Chemmanur, T. J., \& Fulghiery, A. (1999). Theory of the going-public decision. Review of Financial Studies, 12(2), 249-279. https://doi.org/10.1093/rfs/12.2.249

Chen, Y. S., \& Cheng, C. H. (2012). A soft-computing based rough sets classifier for classifying IPO returns in the financial markets. Applied Soft Computing, 12(1), 462-475. https://doi.org/10.1016/j. asoc.2011.08.023

Choe, H., Masulis, R. W., \& Nanda, V. (1993). Common stock offerings across the business cycle: theory and evidence. Journal of Empirical Finance, 1(1), 3-31. https://doi.org/10.1016/0927-5398(93)90003-A

Fałdziński, M., Balcerzak, A. P., Meluzín, T., Pietrzak, M. B., \& Zinecker, M. (2016, September). Cointegration of interdependencies among capital markets of chosen Visegrad countries and Germany. In A. Kocourek, M. Vavrousek (Eds.), $34^{\text {th }}$ International Conference Mathematical Methods in Economics (pp. 189-194). Liberec: Technical University of Liberec.

FESE - Federation of European Securities Exchanges. (2015). Historical Data. Retrieved from http:// www.fese.eu/statistics-market-research/historical-data

Gujarati, D. N., \& Porter, D. C. (2009). Basic econometrics. Boston: McGraw-Hill.

Haefke, C., \& Helmenstein, C. (1996). Forecasting Austrian IPOs: an application of linear and neural network error-correction models. Journal of Forecasting, 15(3), 237-251. https://doi.org/10.1002/(SICI)1099-131X(199604)15:3<237::AID-FOR621>3.0.CO;2-5

Hajek, P., Olej, V., \& Myskova, R. (2014). Forecasting corporate financial performance using sentiment in annual reports for stakeholders' decision-making. Technological and Economic Development of Economy, 20(4), 721-738. https://doi.org/10.3846/20294913.2014.979456 
Ibbotson, R. G., \& Jaffe, J. J. (1975). 'Hot issue' markets. Journal of Finance, 30(4), 1027-1042.

Jovanovic, B., \& Rousseau, P. L. (2004). Interest rates and initial public offerings. National Bureau of Economic Research. Working Paper. Cambridge, MA. https://doi.org/10.3386/w10298

Kubiszewska, K. (2017). Banking concentration in the Baltic and Western Balkan states - selected issues. Oeconomia Copernicana, 8(1), 65-82. https://doi.org/10.24136/oc.v8i1.5

La Porta, R., Lopez de Silanes, F., Shleifer, A., \& Vishny, R. (1997). Legal determinants of external finance. Journal of Finance, 52, 1131-1150. https://doi.org/10.1111/j.1540-6261.1997.tb02727.x

Ljungqvist, A. P. (1995). When do firms go public? Poisson evidence from Germany. Working Paper. Oxford: University of Oxford.

Loeve, M. (1977). Probability Theory I. New York: Springer Science \& Business Media.

Loughran, T., Ritter, J. R., \& Rydqvist, K. (1994). Initial public offerings: International insights. PacificBasin Finance Journal, 2(2), 165-200. https://doi.org/10.1016/0927-538X(94)90016-7

Lowry, M. (2003). Why does IPO volume fluctuate so much?. Journal of Financial Economics, 67, 3-40. https://doi.org/10.1016/S0304-405X(02)00230-1

Maksimovic, V., \& Pichler, P. (2001). Technological innovation and initial public offerings. Review of Financial Studies, 14, 459-494. https://doi.org/10.1093/rfs/14.2.459

Meluzín, T., \& Zinecker, M. (2016). Trends in IPOs: the evidence from CEE capital markets. Equilibrium. Quarterly Journal of Economics and Economic Policy, 11(2), 327-341. https://doi.org/10.12775/EQUIL.2016.015

Modigliani, F., \& Miller, M. (1958). The cost of capital, corporation finance and the theory of investment. American Economic Review, 53(3), 433-43.

Modigliani, F., \& Miller, M. (1963). Corporate income taxes and the cost of capital: a correction. American Economic Review, 48, 261-297.

Myskova, R. (2009, September). Satisfaction of financial managers with accounting information system. In $3^{\text {rd }}$ International Conference on Management, Marketing and Finances, 2009, WSEAS, Houston, USA.

Pagano, M., Panetta, F., \& Zingales, L. (1998). Why do companies go public: an empirical analysis. Journal of Finance, 53, 27-64. https://doi.org/10.1111/0022-1082.25448

Peterle, P., \& Berk, A. (2016). IPO cycles in Central and Eastern Europe: what factors drive these cycles? Czech Journal of Economics and Finance, 66(2), 113-139.

Pietrzak, M. B., Fałdziński, M., Balcerzak, A. P., Meluzín, T., \& Zinecker, M. (2017). Short-term shocks and long-term relationships of interdependencies among Central European capital markets. Economics \& Sociology, 10(1), 61-77. https://doi.org/10.14254/2071-789X.2017/10-1/5

Pohulak-Żołędowska, E. (2016). Innovation in contemporary economies. Oeconomia Copernicana, 7(3), 451-466. https://doi.org/10.12775/OeC.2016.026

PWC, PriceWaterhouseCoopers UK. (2017). IPO Watch Europe. Retrieved form https://www.pwc. co.uk/services/audit-assurance/capital-markets-accounting-advisory-and-structuring/insights/ipowatch-europe-all-editions.html

Rees, W. P. (1997). The arrival rate of initial public offers in the UK. European Financial Management, 3(1), 45-62. https://doi.org/10.1111/1468-036X.00030

Ritter, J. R. (1984). The 'Hot Issue' market of 1980. Journal of Business, 57(2), 215-240. https://doi.org/10.1086/296260

Ritter, J. R. (2011). Equilibrium in the IPO market. Financial Economics, 3, 347-374. https://doi.org/10.2139/ssrn.1822542

Ritter, J. R., \& Welch, I. (2002). A review of IPO activity, pricing, and allocations. Journal of Finance, 57(4), 1795-1828. https://doi.org/10.1111/1540-6261.00478 
Ross, S. M. (2017). Introductory statistics. Academic Press, Elsevier. https://doi.org/10.1016/B978-0-12-804317-2.00031-X

Rydqvist, K., \& Högholm, K. (1995). Going public in the 1980s: evidence from Sweden. European Financial Management, 1(3), 287-315. https://doi.org/10.1111/j.1468-036X.1995.tb00021.x

Scott, J. H. (1976). A theory of optimal capital structure. Bell Journal of Economics, 7(1), 33-54. https://doi.org/10.2307/3003189

Theodoridis, S., \& Koutroumbas, K. (2008). Pattern Recognition. Academic Press.

Żelazny, R., \& Pietrucha, J. (2017). Measuring innovation and institution: the creative economy index. Equilibrium. Quarterly Journal of Economics and Economic Policy, 12(1), 43-62.

https://doi.org/10.24136/eq.v12i1.3 